\title{
CONSEQUENCIAS DA PRESENÇA PORTUGUESA NO REINO DO NDONGO DURANTE O SÉCULO XVII
}

\author{
Luciana Lucia da Silva ${ }^{1}$
}

\section{Resumo}

Utilizando obras dos autores David Birmingham, Joseph Miller e Selma Pantoja que tratam do reino do Ndongo durante o século XVII nos propomos a investigar as consequências da presença portuguesa nessa região. Buscaremos identificar os olhares dos autores em relação às ações dos povos Mbundu no século XVII a partir das demandas geradas pelo contato com os portugueses que buscavam nesse momento se fixar em seu território. Procuramosndo investigar os dados que estes autores nos trazem a respeito das transformações vivenciadas por essa região no período considerado.

Palavras-chave: História de Angola; reino do Ndongo; presença portuguesa.

\section{Abstract}

In using works by authors David Birmingham, Joseph Miller and Selma Pantoja that deal with the Kingdom of Ndongo during the 17th century, we will investigate the consequences of the Portuguese presence in this region. We will identify the authors' perspectives of the Mbundu people's reactions to the demands generated by contact with the Portuguese - who sought to settle into their territory. We also investigate the data that these authors convey about the transformations experienced by the region in the covered period.

Key-words: History of Angola; the kingdom of Ndongo; Portuguese presence.

\section{Introdução}

A proposta do presente artigo é investigar as consequências da presença portuguesa na região que ficou conhecida como reino do Ndongo no século XVII - este era habitado por um subgrupo entre os Mbundu, denominação dada aos falantes do kimbundu, que ocupavam uma larga faixa da África Central Ocidental, entre fins do século XVI e o século XVII - no século XVII. Utilizaremos como fonte produções bibliográficas de três autores que tratam dessa região durante o século XVII e que nos permitirão verificar como os autores, em diferentes posições e momentos, abordam as reações Mbundu frente ao contato com o outro português. Este trabalho se centra na análise de obras dos autores David Birmingham ${ }^{2}$, Joseph Miller $^{3}$ e Selma Pantoja ${ }^{4}$ nas quais

1 Mestranda em História Social no Programa de Pós Graduação em História Social (PPGHIS) do Instituto de História da UFRJ

2 David Birmingham, historiador britânico, é professor da Universidade de Londres, onde leciona História da África. Ele é considerado um dos maiores historiadores da África lusófona e é pioneiro nas pesquisas sobre a moderna historiografia de Angola.

3 Joseph C. Miller obteve o título de Ph. D. em 1972 pela Universidade de Wisconsin, desde esse ano trabalhou na Universidade da Virgínia. É especialista em Historia da África, especialmente Angola, escravidão, tráfico de escravos e História do Atlântico, campos nos quais tem diversas publicações.

4 Selma Alves Pantoja é doutora pela Universidade de são Paulo, é professora da Universidade de Brasília onde leciona História da África. Desenvolveu por muito tempo pesquisas sobre temas como a História Atlântica, comércio de escravos e relações de 
buscaremos perceber como estes autores tratam e interpretam as consequências da presença portuguesa nessa região. Para tal, selecionamos três obras que julgamos as mais propensas a dar o encaminhamento necessário para nossa análise. São elas, A África Central até 1870 - Zambézia, Zaire e o Atlântico Sul de David Birmingham, Poder Politico e Parentesco - Os Antigos Estados Mbundu em Angola de Joseph Miller e Nzinga Mbandi - Mulher, guerra e escravidão de Selma Pantoja. Procuraremos, nesses textos, identificar os olhares dos autores em relação às ações dos povos Mbundu no século XVII a partir das demandas geradas pelo contato com os portugueses que buscavam nesse momento se fixar em seu território, procurando investigar os dados que estes autores nos trazem a respeito das transformações vivenciadas por essa região no período considerado.

A escolha dessas obras se deve ao fato de serem trabalhos de grande importância dentro do estudo da história dos povos Mbundu, pois buscam apresentar uma análise cujo foco está na compreensão das sociedades africanas. Os trabalhos de Joseph Miller e David Birmingham são pioneiros e constituem referência fundamental a todos os que se dedicam ao estudo da história da África Centro-Ocidental. Birmingham foi um dos primeiros historiadores a investigar sobre os arquivos de Angola. O trabalho de Miller tem grande vinculação aos estudos de Jan Vansina, o belga que inaugurou os estudos com a tradição oral africana no campo da História, de quem Miller foi praticamente um discípulo. Selma Pantoja, por sua vez, é uma importante representante brasileira no campo de pesquisa sobre as sociedades Mbundu, foi a primeira historiadora brasileira a dedicar-se aos estudos sobre Angola pré-colonial, em especial sobre os Mbundu, com foco na participação das mulheres.

Tendo como limite espacial o território do reino do Ndongo não é demais lembrar que este se situava na região que ficou conhecida como Angola a partir do início da presença portuguesa no local, em meados do século XVI. Estabelecemos o século XVII como delimitação temporal para a análise das consequências da presença estrangeira no Ndongo por se tratar de um período de grande importância para as relações entre portugueses e africanos, pois, passados alguns anos dos contatos iniciais, que teriam se dado entre as décadas de 1540 e 1560, já podem ser percebidas consequências provenientes desse contato; e pelo fato de ser um período de disputa entre as duas partes pelo domínio da região e pelo tráfico de escravos que nesse período cresce intensamente na região. Além de considerarmos que se trata de um momento de grande importância para se compreender as futuras relações que viriam a ser estabelecidas entre portugueses e os habitantes da 
região. E pelo fato de que muito ainda precisa ser problematizado sobre a participação e agência africana nos acontecimentos referentes a essa presença portuguesa na África Centro Ocidental durante esse período.

É nesse contexto que buscaremos investigar brevemente quais teriam sido as transformações vivenciadas pelos Mbundu em sua dinâmica interna nesse período. Pensar o quanto a chegada desse outro português teria alterado ou influído nas práticas tradicionais e o quanto a própria organização e interesses Mbundu teria mediado as relações e orientado o curso dos acontecimentos que se deram nesse momento é a tarefa a que aqui nos propomos.

\section{Principais consequências da presença portuguesa no Ndongo}

Após a leitura dos textos de David Birmingham, Joseph Miller e Selma Pantoja já indicados, pudemos destacar algumas das principais consequências da presença portuguesa no Ndongo nesse período. As consequências mais recorrentes - identificadas em nossa leitura - e apontadas pelos três autores são: a destruição e o despovoamento dos quais o Ndongo foi vítima; a perda da autonomia governativa; o surgimento de novos Estados assentados no tráfico de escravos para as Américas; e o surgimento da figura de Nzinga Mbandi como liderança guerreira.

\section{Consequências destacadas pelos três autores}

\subsection{A destruição e o despovoamento}

Com relação à destruição e ao despovoamento, David Birmingham nos diz que o Ndongo teria sido a principal vítima da agressão portuguesa ${ }^{5}$, pois, segundo o que ele afirma, os Mbundu do norte foram a primeira e mais direta vítima da ação dos portugueses. De acordo com sua análise, entre as consequências, mais relevantes, advindas com a interferência portuguesa na região está o grave impacto demográfico sofrido devido ao grande número de africanos que passou a sair do porto de Luanda, à guerra e ao transporte, a que eram submetidos os escravizados dos sertões até os portos do litoral, que levava muitas vítimas a morte.

Ao tratar do impacto demográfico, Birmingham nos diz que a resposta demográfica do Ndongo às guerras portuguesas e ao concomitante tráfico de escravizados é difícil de ser analisada

5 BIRMINGHAM, David. África Central até 1870: Zambézia, Zaire e o Atlântico Sul. Luanda: ENDIPU/UEE, s/d. p. 75. 
com precisão. Entre outras coisas, devido ao fato de a perda através da emigração forçada ter sido extremamente alta, talvez proporcionalmente mais alta que em qualquer outra zona de tráfico atlântico de escravos. ${ }^{6}$ Ainda de acordo com o autor esta perda demográfica teria sido acentuada por outros fatores, entre eles o fato de as baixas centrarem-se nos membros mais jovens da população, uma vez que os mercadores de escravos valorizavam homens e mulheres com menos de trinta anos. Outro agravador da situação seria o fato de a área de maior drenagem de escravos ter sido a região central dos Mbundu, dado que as guerras de conquista portuguesa eram uma fonte direta de fornecimento, o que contrastava com a prática normal do tráfico de escravos na qual a captura ocorria na periferia de fortes reinos. Além disso, o tráfico de escravos angolano teria representado uma muito mais violenta e arbitrária exigência de vítimas do que o tráfico de outras regiões, onde os chefes africanos permaneciam senhores de sua própria casa e podiam tomar decisões acerca de sua participação no tráfico. De acordo com o defendido por Birmingham:

Em Angola, por outro lado, o sistema de monopólio comercial português, e as coações militares sobre a fixação dos preços, impediam os chefes do Ndongo de qualquer iniciativa econômica. Recebiam apenas uma diminuta vantagem econômica do comércio e absolutamente nada pelas perdas de guerra. $^{7}$

Apesar de acostumados a enfrentar grupos invasores, o desafio que os portugueses representavam era de natureza diferente, não só implicava um confronto militar direto, mas também um muito mais odioso esvaziamento demográfico que escoava para longe a base da vitalidade do reino.

O tráfico de escravos não foi, porém, a única sangria demográfica de Angola, o autor nos diz que houve uma série de migrações de refugiados, que podem ter desempenhado um papel tão importante como o tráfico de escravos em reduzir Angola, do rico e populoso país cujo testemunho foi dado pelos jesuítas no século XVI, às terras desertas, descritas pelos capuchinhos do século XVII. Comunidades inteiras se afastavam da fronteira escravizante em direção ao norte, leste e sul. A zona de refúgio mais próxima era o sul, através do rio Kwanza, até a Kisama, o Libolo e, mais para lá, o planalto de Benguela. Os povos Ndembu, do sul do Congo, também absorvem muitos refugiados Mbundu. A terceira e mais importante área de refúgio, durante as guerras de Angola, era no leste, mais afastado da devastação militar. Birmingham nos diz, ainda, que as migrações para leste estiveram, inicialmente, relacionadas com o destino da casa real do Ndongo após a tomada 
pelos portugueses de Cabaça, capital do reino ${ }^{8}$.

Em sua análise, Joseph Miller também considera a destruição e o despovoamento uma das consequências mais relevantes da presença portuguesa no Ndongo. Segundo ele, Manuel Cerveira Pereira (governador de 1615 a 1617) teria encorajado os Imbangala ${ }^{9}$ a devastar os Mbundu locais sem qualquer restrição, causando enormes destruições. Os Imbangala eram grupos que, segundo Miller, teriam surgido a partir da fusão, ocorrida em algum momento do século XVI, entre titulares Lunda, que abandonaram suas linhagens e se deslocaram para oeste, com o kilombo (sociedade iniciática guerreira dos Ovimbundo). Oponentes locais à postura deste governador informaram a Lisboa que o uso incontrolado dos Imbangala estava prejudicando os interesses da coroa no tráfico. Cerveira foi substituído por Luis Mendes de Vasconcelos (1617-1621) que confirmou que seu antecessor havia deixado Angola em condições deploráveis, tanto do ponto de vista dos Mbundu como da Coroa:

Com uma base realmente um tanto mais sólida, Vasconcelos relatava que os exércitos aliados de Portugueses e Imbangala tinham destruído completamente muitos sobas, ou titulares hereditários Mbundu. Alguns sobas tinham perdido tanta da sua gente que já não podiam satisfazer o tributo directo em escravos exigido pela Coroa. ${ }^{10}$

Ele argumentava que isso se dava devido à parceria com os Imbangala, mas que não podia levar tal parceria ao fim, pois os traficantes locais se oporiam; para estes traficantes de escravos a colônia fracassaria sem o apoio Imbangala. A princípio Vasconcelos teria tentado expulsar os Imbangala de Angola, porém, vendo a importância destes para a manutenção do tráfico, mudou seus planos e juntou-se aos Imbangala numa razia que varreu regiões muito para leste, entrando no Ndongo e para norte atravessando o Lukala e penetrando no Congo. Juntos, portugueses e Imbangala, atacaram os mais poderosos chefes governantes dessa região, incluindo o ngola a kiluanje, neste momento Ngola Mbandi que havia assumido em 1617. Esta guerra teria causado tanta devastação que o comércio parou completamente, os caminhos ficaram fechados e a destruição generalizada das colheitas trouxe a fome por todo lado $^{11}$.

Quanto à destruição e ao despovoamento Selma Pantoja nos diz que ao longo do século XVII os portugueses combateram o Ndongo para destruir o povo Mbundu e incrementar o

$8 \quad$ Ibidem, pp. 76-77.

9 Joseph Miller expõe dados sobre as origens dos grupos Imbangala no capítulo "O Kilombo dos Imbangala - Uma Solução Radical" in. MILLER, Joseph C. Poder Político e Parentesco: os antigos Estados Mbundu em Angola. Luanda: Arquivo Histórico Nacional, 1995. pp.149-173.

10 MILLER, Joseph C. Op. cit., p. 194.

11 Ibidem, pp. 194-196. 
comércio. Em sua análise Selma Pantoja fala da presença portuguesa no século XVII como uma grande agressão aos estados africanos, ela concorda com Birmingham ao afirmar que o Ndongo teria sido a maior vítima da agressão dos portugueses. $\mathrm{O}$ que teria se dado, principalmente, em decorrência do confronto militar e do fluxo do tráfico de escravos que teriam destruído as bases do Ndongo $^{12}$. Pois, segundo ela, além de comerciar e expandir sua fé, os lusos queriam estabelecer um governo no local, garantidos por sua superioridade militar. Como a meta era aumentar o número de escravos, a cada novo governador os métodos se tornavam mais violentos, novas fortificações eram estabelecidas e as lutas locais forneciam um número crescente de escravos. Guerras eram iniciadas por diversos motivos, por exemplo, quando um parceiro africano não se comportava dentro do esperado era punido com uma campanha militar. Outras vezes o objetivo era apenas, explicitamente, aumentar o número de cativos.

Dessa forma, Selma Pantoja defende que os contatos comerciais trouxeram significativas transformações ao Ndongo, que foram decorrência principalmente da expansão do tráfico de escravos na região e da disputa pelo seu controle. As campanhas militares promovidas pelos portugueses com o objetivo de obter um maior número de escravos e submeter aà região ao seu domínio foram extremamente destrutivas. Para a autora, uma das maiores sequelas, ao lado das transformações advindas dos contatos comerciais, teriam sido as guerras que massacraram a população, já no início de 1617 o governador de Luanda declarou guerra ao Ndongo e muitas foram as guerras subsequentes, durante as guerras matava-se grande parte da população e transformava os prisioneiros em escravos.

Assim, constatamos que uma das maiores consequências, apontadas por Selma Pantoja, foi a perda de efetivos humanos que levou ao despovoamento e à destruição daquela região. Segundo a autora:

A maior vítima dessa contínua agressão foi o estado do Ndongo: o confronto militar e o fluxo do tráfico demoliram as suas bases. No século XVII os testemunhos portugueses e holandeses referem-se a 10.000 escravos retirados de Angola por ano. Esta perda se dava especialmente entre os elementos mais jovens e foi extremamente alta. ${ }^{13}$

Além disso, ela afirma que pode se constatar que a partir do contato com os portugueses o Ndongo foi vítima de crises constantes. O tributo e as taxas adicionais criavam uma situação

12 Ibidem, pp. 91-111.

13 PANTOJA, Selma. Nzinga Mbandi: mulher, guerra e escravidão. Brasília: Thesaurus, 2000. p. 111. 
extorsiva que impedia o vassalo de pagar tudo. A coleta de tributos se dava sob a forma de pilhagem e o pagamento era em escravos, criando um ambiente de rebelião. Selma defende que, em sua ação, os portugueses se aproveitavam da situação de guerra, fome e pilhagem para capturar escravos. A migração para o sul foi uma das alternativas encontradas pela população, muitos Mbundu teriam fugido para a região de Benguela procurando zonas menos áridas e sem guerras. Ela nos diz que esse contexto levou a região ao despovoamento, para o qual contribuíram, além da guerra e do tráfico, a seca e as epidemias.

\subsection{A perda da autonomia governativa}

A segunda consequência proveniente da ação portuguesa no Ndongo que pode ser identificada na obra dos três autores é a perda da autonomia governativa. De acordo com a análise de David Birmingham, uma das consequências mais relevantes advindas com a interferência portuguesa na região teria sido a perda da autonomia governativa à medida que os fortes e guarnições portuguesas avançavam pelo território em direção à capital real ${ }^{14}$.

Em relação a esse fator, Birmingham sugere que o declínio, em trinta anos, do poder político e militar do Ndongo teria se acentuado durante a crítica campanha de 1617, na qual os invasores portugueses penetraram na zona arborizada que separava a planície costeira do planalto, acrescentando um novo forte à sequência de avanço português. Em 1618, Luís Mendes de Vasconcelos teria feito uma incursão no próprio planalto e invadido o coração do reino. Já no momento em que os portugueses apostavam no retorno ao comércio como principal meio para a obtenção de escravos, abandonando a estratégia de guerra, o reino do Ndongo mantinha uma política de contração e resistência. Pois, segundo Birmingham, ao contrário do Congo, o Ndongo teve dificuldade em absorver, controlar e usar em benefício próprio, uma comunidade mercantil estrangeira $^{15}$. Com o tempo, da mesma forma que falhou no estancamento da hemorragia interna provocada pelo tráfico de escravos, o Ndongo perdeu, cada vez mais, a autonomia governativa, à medida que os fortes e guarnições portuguesas avançavam pelo seu território. Além disso, os portugueses expulsaram Nzinga Mbandi, pretendente ao título de soberana do Ndongo após a morte do último ngola em 1617, decididos a governar o reino de forma indireta. Por isso, concederam o título de ngola a um chefe chamado Aire Kiluanji, para que este pudesse cooperar com a política

14 BIRMINGHAM, David. Op. cit., p. 76.

15 Ibidem, p. 42. 
portuguesa para a região ${ }^{16}$.

De acordo com Joseph Miller, quando os dois invasores, os portugueses e os Imbangala, uniram as suas forças em busca de escravos, condenaram à derrota os antigos reis Mbundu. De acordo com o autor, eles conseguiram que os ngola a kiluanje fossem reduzidos da situação de monarcas de um reino vigoroso e em expansão, em 1600, para a de governantes fantoches e quase sem poder após $1630^{17}$.

Um dos fatores destacados por Miller para esta perda da autonomia governativa do Ndongo teria sido a gradativa penetração feita pelos portugueses em seus territórios através da construção de fortalezas. Segundo Miller, entre 1610 e 1620 os governadores portugueses concentraram seus esforços na penetração do estado do ngola a kiluanje, construíram um presídio num local chamado Hango, este serviria de base segura para desencadear futuras operações mais longe.

As precárias posições de portugueses e Imbangala, a norte do Kwanza mantiveram-nos num firme acordo contra os subversivos intentos das linhagens Mbundu. Assim, em 1612, teria se dado a aliança formal entre os Imbangala e os portugueses. Segundo o autor, governadores portugueses teriam recorrido à ajuda de tropas auxiliares africanas.

Logo depois, em 1617, a mudança do forte Hango para Ambaca ajudou os portugueses no movimento em direção a capital do Ndongo, os portugueses ocupam definitivamente o território na margem norte do Kwanza estendendo-se para leste até os postos mais avançados em Ambaca. Ambaca teria sido a posição estratégica para uma força mercenária estacionada como tampão entre o Ndongo e as fracas forças portuguesas a jusante ${ }^{18}$. Dessa forma, ele defende que exércitos mercenários dos Imbangala teriam formado a espinha dorsal das expedições portuguesas que colocaram o Ndongo na defensiva e substituíram Mbande a Ngola pelo ngola a kiluanje fantoche ${ }^{19}$. O autor salienta, ainda, que depois da derrota final de Hari a Kiluanje, em 1671, o governo português se estenderá até Pungo Andongo. Além disso, o apoio europeu a detentores de títulos subordinados, insatisfeitos, teria levado à deposição de autoridades de maior expressão, fortes e independentes, substituindo-os por fracos fantoches.

De acordo com Selma Pantoja, no século XVI, o Ndongo tinha vantagens em relação ao

16 Ibidem, p. 78.

17 MILLER, Joseph C. Op. cit., p.174.

18 Ibidem, pp. 192-193.

19 Ibidem, p. 218. 
Congo, pois estava mais para o interior, podendo, sem contato direto com os europeus, manter suas trocas sem a interferência lusa, o que lhe permitiu se fortalecer através do comércio de escravos. Mas, segundo a autora, desde finais desse século os portugueses se estabeleceram na região de Angola, canalizando esforços para tornar a região uma área sob seu completo domínio. Com a fundação de Luanda em 1575 iniciou-se a campanha para a obtenção do monopólio comercial e para encontrar as supostas minas de prata de Cambambe ${ }^{20}$. A vila de Luanda situada em território africano e governada por portugueses seria o primeiro passo na conquista militar do Ndongo, que levou mais de um século para se efetivar. O início do século XVII testemunhou grandes avanços dos portugueses no sentido de aumentar o comércio de escravos em Luanda, transformando-a no principal porto pelo qual eram exportados os escravos para as Américas. A região da África Central que incluía Loango, Cabinda e Luanda foi durante os séculos XVII e XVIII responsável por um quarto da exportação de escravos para as Américas e a partir de 1830 predominou sozinha no tráfico ${ }^{21}$. Pantoja diz que os Mbundu estiveram intimamente relacionados com este crescimento comercial, ela afirma que as altas e baixas desses estados no fornecimento implicavam nos interesses das lideranças africanas em manejar esses acordos com os portugueses. Para manter o monopólio do fornecimento de escravos aos europeus, os comerciantes africanos eram os próprios representantes do estado e obrigavam as linhagens ao pagamento das taxas; a recusa era punida com ataques onde os prisioneiros eram transformados em escravos. À medida que crescia a demanda por escravos no litoral, mais se comprometiam os seguimentos dominantes africanos com o comércio de escravos. Segundo a autora, os chefes africanos tinham interesse em manter os contatos comerciais, mas pensando fortalecer-se perderam o controle do comércio, alguns se fortaleceram, outros acabaram destruídos.

O contato contínuo dos portugueses com a região teria levado a um maior controle do comércio e a uma maior ingerência interna nas sociedades Mbundu por parte dos europeus ${ }^{22}$. Pois, ao subjugar cada comunidade Mbundu, os portugueses buscavam interferir diretamente na organização social daqueles povos. Pantoja usa como exemplos a tentativa por parte dos portugueses de combater a poligamia, de interferir nos cultos, ritos e nas regras de sucessão das chefias do Ndongo. Ela nos diz que a administração portuguesa se dava a partir de controle indireto da população africana, mas que, quando necessário, se fazia ingerência nos assuntos internos. Dessa forma, os portugueses buscaram conhecer a organização e o funcionamento das sociedades Mbundu

20 PANTOJA, Selma. Op. cit., p. 90.

21 Ibidem, p. 130.

22 Ibidem, p. 93. 
para utilizar esse conhecimento em benefício próprio. Sabiam que os sobas e os macotas compunham a elite do estado e jogavam as cartas definitivas do poder e que eram encarregados de guardar a tradição da linhagem, por isso buscavam se aproveitar destes grupos dando-lhes especial atenção quando queriam submeter determinada região. Em um trecho do relatório do governador Fernão de Souza (1624-1630), no qual ele se refere ao ataque à Nzinga, o governador aconselha o capitão-mor a aprisioná-la e que, caso não conseguisse, submetesse os sobas e os macotas por serem estes que elegiam os reis, dessa forma tentariam garantir a não legitimidade de Nzinga como rainha ${ }^{23}$. Isso demonstra que tinham o conhecimento de que esses conselheiros e os sobas detinham um espaço importante no processo decisório, lhes cabendo o ato de legitimar o poder do próprio ngola. Também sabiam que era necessário transformar os sobas em aliados do comércio, para que estes abrissem as feiras, o comércio e a passagem.

Além disso, Selma Pantoja concorda com David Birmingham e Joseph Miller quando defende que a perda da autonomia governativa do Ndongo se deu a partir da construção de fortalezas próximas à sua capital. Ela lembra que durante o governo de Luis M. de Vasconcelos o forte Hango foi transferido para Ambaca que ficava a um dia de caminhada para a capital Mbundu uma expressa afronta a soberania do Ndongo. Pantoja também nos diz que a substituição de antigas linhagens teria sido um fator relevante nesse processo. Ela aponta para o fato de o governo de Luanda ter ajudado a impor sobas, a eles aliados, como ngola, como defendido por Birmingaham e Miller.

1.3 O surgimento de estados assentados no tráfico de escravos e o surgimento de Nzinga Mbandi como liderança guerreira

Os três autores também concordam quando apontam o surgimento de novos estados assentados no tráfico de escravos para as Américas e o surgimento de Nzinga Mbandi como liderança guerreira - fatores que, como veremos, têm grande relação entre si - como consequências da presença portuguesa no Ndongo.

Birmingham fala do estabelecimento de um pequeno Estado entre os Mbundu ocidentais, ${ }^{24}$ dizendo que à medida que a resistência Mbundu decresceu, uma pequena colônia branca criou-se

23 Ibidem, pp. 133-134.

24 BIRMINGHAM, David. Op. cit., p. 41. 
em Angola; apenas no alto Kwango teria se mantido uma verdadeira independência dos Mbundu. Os colonos teriam conseguido estabelecer um pequeno Estado entre os Mbundu ocidentais a partir do qual cobravam o pagamento de tributo na forma de escravos. Embora o plano original português de criar uma colônia de povoamento fosse subvertido pelos interesses do tráfico de escravos, Birmingham afirma que uma pequena colônia evoluiu em torno da cidade de Luanda, sua população era uma enorme miscelânea social e racial ${ }^{25}$.

Através da leitura da obra de David Birmingham, podemos perceber que ao mesmo tempo em que os portugueses lutavam para manter seu estado colonial em Angola, Matamba e Kasanje cresciam como reinos intermediários no Kwango. Segundo o autor, o crescimento dos estados de Matamba e Kasanje esteve bastante ligado aos processos vividos pelo Ndongo nesse momento e, por isso, não pode deixar de ser citado quando analisadas as transformações dessa região durante o século XVII.

De acordo com a análise de Birmingham, a destruição do reino do Ndongo originou uma nova chefia militar do que havia sido sua decadente dinastia, a qual foi capaz de resistir ao avanço português. Segundo ele, o símbolo deste renascimento foi uma princesa real chamada Nzinga, cuja personalidade dominou a cena angolana no meio século seguinte ${ }^{26}$. Nzinga teria tomado conta da chefia do Ndongo objetivando acabar com a guerra que ainda devastava o centro do planalto de Luanda, obter dos portugueses o reconhecimento diplomático que tinham adotado para com o Congo e estabelecer uma regular e rentável relação comercial com Luanda. Seu interesse era de que os portugueses reconhecessem a independência do Ndongo e concordassem em fazer comércio com esse país, assim o tráfico de escravos poderia ser levado a cabo na periferia do reino, deixando o centro em paz. Não chegando a um acordo, os portugueses expulsaram Nzinga do Ndongo. Após esse evento, Nzinga se estabeleceu na Matamba e, depois de ter treinado suas novas forças de combate, estava pronta para enfrentar os portugueses de novo e tentar recuperar o Ndongo. Assim, segundo Birmigham, nesse momento, desde meados da década de 1620 até ao fim da década de 1630 a guerra prosseguiu com mais intensidade que nunca ${ }^{27}$. Não podemos desconsiderar que Nzinga Mbandi havia construído, após ter sido conduzida ao afastamento do Ndongo, um eficiente reino comercial e que, na altura de sua morte, em 1663, a Matamba já tinha se tornado um dos principais intermediários para o tráfico de escravos.

\footnotetext{
25 Ibidem, p. 75-80.

26 Ibidem, p. 77

27 Ibidem, p. 78.
} 
Enquanto Nzinga consolidava o poder na Matamba, novos desenvolvimentos políticos tiveram lugar entre os Imbangala estabelecidos em Angola. O mais importante portador de um título entre os Imbangala, em princípios do século XVII, era o Kasanje, um chefe que em 1617 apoiou ativamente a invasão do planalto de Luanda e a derrota do Ndongo. Depois disso, esses grupos, cuja ação era encarada por testemunhas como predatória, começaram a se fixar em regiões próximas, o Kasanje se retirou para o vale do Kwango durante a década de 1630 e iniciou a criação de um império comercial similar ao reino de Nzinga na Matamba ${ }^{28}$. Este recebeu o nome de Kasanje e era, segundo Birmingham, uma potência militar de grande importância. Esses são exemplos que nos ajudam a perceber que o século XVII assistiu a um período de considerável desenvolvimento político ao longo das novas rotas comerciais da África Central.

De acordo com o que Miller defende em sua análise, portugueses e Imbangala teriam juntado as suas forças para estabelecer um novo conjunto de estados traficantes de escravos que num certo sentido diferiam pouco quanto ao seu impacto sobre os Mbundu, quer fossem governados por europeus (Angola) ou por africano ${ }^{29}$. O pequeno Estado português, Angola, substituiu os detentores de títulos Kongo nessa região, planície costeira a norte do Kwanza, e o ngola a kiluanje nas antigas províncias centrais de Ndongo e Lenge ${ }^{30}$. No caso dos estados governados por africanos, o principal titular de cada bando Imbangala estabelecia-se como um rei Mbundu que substituía, na maioria dos casos ao norte do Kwanza, alguma espécie de domínio exercido pelo ngola a kiluanje, criando um novo estado baseado no recrutamento dos varões locais para a associação ao kilombo, oO que privava a parte mais produtiva da população local de sua anterior pertença às linhagens Mbundu, além de sujeitá-la à direta autoridade do rei Imbangala e aos vunga (chefes menores) por ele nomeados. Ao serem tiradas de suas linhagens, essas pessoas estariam morrendo na concepção dos Mbundu.

Do ponto de vista militar, todos os reinos Imbangala entre os Mbundu que constituíram acampamentos de mercenários estabelecidos nas franjas da Angola portuguesa eram dominados por guerreiros especializados que, em tempos normais, capturavam agricultores locais para vender como escravo e que, em tempos de guerras, se juntavam às expedições portuguesas para combater,. aAssim como podiam se juntar a traficantes não ligados à coroa portuguesa ${ }^{31}$.

28 Ibidem, pp. 78-79.

29 MILLER, Joseph C. Op. cit., p. 218

30 Ibidem, p. 174.

31 Ibidem, pp. 191-192. 
Segundo o autor:

Todos os reinos que emergiram das cinzas das guerras angolanas, ou seja, a própria Angola, Kalandula, Kabuku, Kasanje, os reis mais tardios de Jinga, Kasanje, Holo, mwa Ndonje (bem como vários reinos dos Ovimbundu a sul do Kwanza) ficaram a dever as suas origens aos governantes dos Kilombo. Eles se tornaram os estados dominantes na Angola do século dezoito, substituindo completamente os anteriores reinos do Ndongo, Libolo, Kulembe $^{32}$.

Mas, embora posteriormente as linhagens tivessem vencido o kilombo, não puderam banir igualmente os reis Imbangala. Muitos chefiaram os reinos Imbangala "Mbundizados" que prosperaram como os principais fornecedores de escravos para os comerciantes europeus ao longo do século XVIII e parte do XIX: Holo, Jinga, Kasanje, Mbondo. Todos eles prosperaram sob a chefia dos detentores de títulos Imbangala, estabelecidos nas franjas do território controlado pelos portugueses $^{33}$. Miller salienta que os reis Imbangala do norte conseguiram se colocar como governantes das linhagens dos Mbundu em parte devido a sua aliança com os portugueses.

Assim como Birmingham, Miller afirma que Kasanje e Matamba são dois importantes exemplos de estados que se desenvolveram nessa época em consonância com o tráfico de escravos. Kasanje juntamente com Matamba, se tornou o principal fornecedor de escravos para o tráfico que constituía o suporte do estado português de Angola até meados do século XIX. Porém, Kasanje e Matamba se mantiveram fiéis aos títulos e posições Lunda/Mbundu, o que impede que eles sejam representativos do caso mais comum dos bandos Imbangala, mais próximos da costa, que dependiam em larga medida da ajuda portuguesa para sobreviver. Kasanje e Matamba proclamavam sua ligação ao kilombo dos Imbangala, mas assentavam sua legitimação em títulos Lunda/Mbundu. Miller nos diz que Nzinga, governante de Matamba e pretendente ao título ngola a kiluanje, tinha tentado restabelecer em Matamba o seu título após os portugueses terem colocado fantoches no lugar dos reis originais do Ndongo. Na década de 1620 ela adotou os ritos do kilombo e considerava-se a si própria Imbangala. Durante esta década Nzinga tinha complementado a sua posição como ngola a kiluanje com um casamento simbólico com o Kaza, que lhe deu a posição de Tembanza (primeira mulher) do chefe do kilombo, o que permitiu Nzinga assegurar a liderança sobre o que restava dos Imbangala do Kulaxingo, após sua dispersão em 1619. Nzinga deslocou-se

32 Ibidem, p. 218.

33 Ibidem, p. 259. 
para norte, para o antigo reino da Matamba, apenas depois da sua estratégia de procurar refúgio entre os vários grupos de Imabngala se ter revelado incapaz de proteger sua posição no Ndongo. Sob a chefia de Nzinga, o reino de Matamba tinha se tornado, pela década de 1640, um dos mais poderosos estados orientais dos $\mathrm{Mbundu}^{34}$. Seu reino desenvolveu-se de forma muito atípica em relação aos outros estados dos Imbangala noutras zonas do norte de Angola, uma vez que ela foi capaz de manter uma oposição às atividades portuguesas em Angola muito mais consistente. Matamba acabou por ser a exceção que ilustra a razão fundamental porque a maioria dos reis Imbangala manteve relações tão estreitas com os portugueses. Nzinga foi a única Imbangala do norte, que reivindicou uma autoridade política (certos títulos locais na Matamba) derivada do sistema autóctone de títulos Mbundu.

Ainda de acordo com Joseph Miller, a economia do tráfico de escravos contribuiu para manter Nzinga independente do controle português até 1656. A rota de escravos que se desenvolveu, durante a década de 1630, na Matamba até aos holandeses no litoral, através do Ndembu, assegurava-lhe o acesso às mercadorias europeias independentemente das suas relações com os portugueses de Luanda. Como parte da sua política de atacar constantemente os interesses oficiais portugueses, ela cooperou com os holandeses enquanto estes tiveram o controle de Luanda, de 1641 a 1648. Esta ocupação abriu caminho para a exportação de escravos em larga escala a partir de Matamba e esse impulso elevou Nzinga à estatura do mais poderoso governante no interior na década de 1640. Sua supremacia, porém, durou apenas até 1648, quando os portugueses expulsaram os seus aliados e reabriram o tráfico com Kasanje, no decurso da década de 1650, oO que a preparou para chegar a uma reconciliação com os portugueses em $1656 .{ }^{35}$

Selma Pantoja defende que os estados Mbundu no século XVII tiveram várias semelhanças no referente a seu traço básico, a estrutura de parentesco e as transformações sociais ocorridas a partir do comércio atlântico ${ }^{36}$. E afirma que a partir de meados do século XVII, os reinos africanos envolvidos com o comércio atlântico passaram a se localizar em torno das rotas que levavam à Luanda. Surgiram, assim, poderosas chefias militares que se dedicavam à busca por escravos. Nzinga Mbandi incorpora esse tipo de liderança guerreira ao se deslocar para Matamba. A expansão e o fortalecimento dos grupos Imbangala é também uma questão que vai marcar a região do Ndongo nesse momento. O líder Imbangala Kasanje, por exemplo, ao se fixar na região entre os rios Lui e Kwango, tornou-se chefe de um poderoso e comercialmente forte estado, o Kasanje, que se tornou

34 Ibidem, pp. 201-218.

35 Ibidem, pp. 205-206.

36 PANTOJA, Selma. Op. cit., p. 129. 
importante abastecedor de escravos para os portugueses na África Centro-Oeste.

Segundo Selma Pantoja, após a morte de Ngola Mbandi, que, segundo alguns contemporâneos, teria sido envenenado por Nzinga, entre 1623 e 1663, ano de sua morte, o cenário da região foi dominado por ela ${ }^{37}$. Na busca pelo monopólio do tráfico de escravos os portugueses conseguiram a adesão dos povos Imbangala, mas tiveram de enfrentar a fabulosa resistência de Nzinga. Ela se aliou aos Imbangala e adotou os costumes deste grupo, acolheu escravos fugitivos dos portugueses, convenceu os chefes sob controle dos lusitanos a se juntarem a ela. Os fugitivos reforçavam o contingente militar de Nzinga e constituíam um exército leal desprovido de laços de linhagem.

De acordo com Pantoja, sua ascensão ao poder pode ser encarada como um rompimento das normas estabelecidas pelas linhagens tradicionais, os macotas não admitiam que o título ngola pertencesse a uma mulher. Assim, tanto no Ndongo, quanto em Matamba, ela utilizou força militar para chegar ao poder. Sobas vassalos da Coroa passavam para o seu lado na expectativa de que com esta força militar ela fizesse frente às tropas portuguesas. Apesar de não ser a única liderança guerreira surgida nesse momento, o caso de Nzinga é interessante ao se tornar exceção na constituição de um exército fiel de cativos. Por meio do apoio desse grupo de escravos tentou apoderar-se do poder e do título de ngola, este grupo lhe permitiu recompor suas forças diversas vezes.

Refugiada em Matamba, Nzinga tornou-se soberana da região. Apesar disso, jamais desistiu da intenção de retornar ao Ndongo. Nzinga era temida por ter adotado os ritos Imbangala, sobrevivido à varíola e à perseguição dos portugueses. Por isso, a população lhe atribuía poderes sobrenaturais ${ }^{38}$. Segundo Selma Pantoja, “a resistência de Nzinga, 'aquela beliculosa mulher', como a descreveu Cadornega, será o grande entrave para o fluxo comercial [português] ao longo do século XVII". ${ }^{39}$ Sem renegar o tráfico negreiro, Nzinga não aceitava as regras impostas pelos lusos. $\mathrm{Na}$ defesa de seus interesses lutou apoiada em seu poderio militar e em sua habilidade política para forjar pactos que liderava, provando sua tenacidade na busca de regras comerciais favoráveis. Nzinga teria lutado contra os portugueses, para manter a autonomia do Ndongo, e contra os grupos Imbangala que saqueavam suas rotas comerciais. Tornou-se poderosa militarmente e sabia adaptarse às diversas situações, quando foi preciso aliou-se a grupos locais ou a estrangeiros, adotou ritos

37 Ibidem, p. 105.

38 Ibidem, pp. 114-127.

39 Ibidem, p. 94. 
Imbangala e o próprio cristianismo ${ }^{40}$.

\section{Consequências apontadas por apenas um dos autores}

Entre as consequências provenientes da interferência portuguesa no reino do Ndongo destacadas por Selma Pantoja e que não aparecem como pontos relevantes nas análises de David Birmigham e Joseph Miller, estão a referência ao contato com um "mundo atlântico" e a mudança no tipo de escravidão. De acordo com Pantoja, os Mbundu se colocaram em posição estratégica para se tornarem grandes fornecedores de escravos e, ao participarem do comércio de escravos, entraram em contato com o mundo atlântico ${ }^{41}$. $\mathrm{O}$ vinho português e a cachaça brasileira demonstram isso ao serem usados como produtos de troca no comércio de escravos. Além disso, a autora faz referência ao fato de em 1648 tropas brasileiras ajudarem a expulsar os holandeses de Luanda lembrando que, a partir desse momento, funcionários administrativos provenientes do Brasil passaram a ocupar importantes cargos em Luanda, demonstrando a existência de uma identificação administrativa entre Rio/Salvador/Recife e Luanda que só pode ser entendida a partir da percepção de que estavam em jogo interesses escravistas na região. De acordo com Pantoja, já na época diziase que sem a mão de obra fornecida por Angola não se produzia açúcar. Assim, segundo a autora, constata-se que, através da convivência e do encontro de familiaridades com este novo universo, intercâmbios eram promovidos através do Atlântico.

A consequência de maior enfoque na análise de Selma Pantoja é a escravização de pessoas livres e o maior desenvolvimento da escravidão interna, em proveniência do aumento do número de cativos na comunidade em função da demanda do tráfico. Segundo a autora, a mudança radical do papel dos estados africanos no tráfico, como é o caso do Ndongo, ocorreu de forma conjunta à mudança do tipo de escravos e da escravidão interna ${ }^{42}$.

Do tipo de escravos por que o status do escravo que, apesar de não ser nitidamente definido, em qualquer situação significava a perda de direitos e privilégios que com o tempo poderiam vir ser readquiridos, em meados do século XVII, com o uso comercial de forma intensiva do escravo e com a luta pelo controle do comércio, essa situação teria se alterado profundamente. Além disso, a preferência, que no contexto africano era por mulheres, passa a ser por pessoas do sexo masculino,

40 Ibidem, p. 141.

41 Ibidem, 129.

42 Ibidem, p. 129. 
o que se explicava, segundo a autora, à medida que o trabalho produtivo feminino era predominante no continente. E da escravidão interna porque antes da chegada dos portugueses e antes daquela região se transformar no principal fornecedor de escravos para as Améericas, a escravidão no Ndongo mantinha-se como uma instituição não hegemônica na organização social dos Mbundu. Ela era uma instituição importante dentro da estrutura de parentesco e linhagem não sendo, porém, essencial no processo produtivo. A partir da integração ao tráfico atlântico a situação se transforma e o escravo de elemento acidental passa a elemento comum. Segundo Pantoja, esse uso do escravo no tráfico atlântico só foi possível pelo fato de as lideranças africanas terem reajustado os mecanismos internos de escravidão e por terem desenvolvido canais próprios de apoio ao crescimento comercial ${ }^{43}$. Em sua análise, ela defende que:

A pressão do tráfico, por um lado, e as necessidades dos governantes africanos, por outro, explicariam as mudanças dos mecanismos de produção e circulação do escravo que por essa época [...] extrapolavam a capacidade interna dessas comunidades. A sua utilidade na percepção dos dirigentes africanos assentava-se na ideia de que [...] era fundamental para sua sobrevivência política se manterem integrados ao tráfico. ${ }^{44}$

Assim, a escravidão se torna a pena para os mais insignificantes delitos, de forma que as leis sociais passam a ser utilizadas para satisfazer a demanda do tráfico. Porém, as crises constantes após os contatos com os europeus, a substituição das antigas linhagens e as tensões e conflitos que caracterizam as relações entre o Ndongo e os portugueses não permitem, segundo a autora, fazer uma profunda análise do processo que conduziu os indivíduos à escravidão entre os Mbundu. Mas Selma chama a atenção para o fato de que a escravidão é pensada pela última geração de africanistas de forma a conceber o tráfico de escravos entre africanos e europeus a partir de um contexto de mudança social, tornando elementos como demografia e economia indispensáveis à análise $^{45}$. Percebemos, então, que a mudança do tipo de escravos e a mudança das formas de escravidão acompanham a mudança do papel dos estados africanos no tráfico atlântico, ou seja, quanto maior é a intensidade da participação no tráfico, mais se altera o quadro da escravidão.

Entre as consequências da presença portuguesa no Ndongo presentes na análise de David Birmingham, a que aparece de forma destacada apenas nesse autor é a mistura de tradições

\footnotetext{
43 Idem.

44 Ibidem, p. 146.

45 Ibidem, p. 33.
} 
africanas e europeias. Segundo Birmingham, a população mestiça que se desenvolveu em Luanda era social e economicamente importante e muitos pombeiros (agentes de comércio itinerantes, representantes da Coroa portuguesa, que percorriam o interior) eram mestiços. A cultura dos estados intermediários no comércio de escravos ao longo do Kwango era, segundo ele, uma curiosa mistura das tradições africanas e européias:

Os tratados eram redigidos em língua diplomática portuguesa, mas o idioma comercial era usualmente o Kimbundu, largamente falado pela comunidade branca. Apesar do Cristianismo ter sido formalmente introduzido nos estados do Kwango, a religião tradicional permaneceu muito forte para ser ignorada, mesmo pelos Europeus. ${ }^{46}$

Desse modo, Birmingham defende que a troca recíproca entre culturas era notória mesmo em Luanda, onde os pais brancos eram muito criticados pelo fato de os filhos não falarem português e por praticarem rituais pagãos. Muitas vezes a cultura de Portugal cedeu perante a cultura Mbundu, no que se refere ao idioma, aos costumes, a religião e mesmo na medicina; mas os laços com os portugueses eram renovados com a chegada de novos portugueses que vinham para aí trabalhar. Desse modo, segundo o autor, “o Ndongo teria sido obrigado a resistir, e quando, 'palmo a palmo', a resistência falhou, os Mbundu foram absorvidos na comunidade semi-colonial luso-africana de Angola com sua síntese cultural". ${ }^{47}$

O que difere a análise de Joseph Miller da dos demais é o fato deste autor considerar que as transformações no Ndongo teriam se dado a partir de uma ação conjunta de portugueses e Imbangala, o que se pode constatar ao longo desse artigo. A partir da leitura de Miller, percebemos que o autor não considera as transformações ocorridas no reino do Ndongo a partir da chegada dos portugueses de forma isolada. Ele defende que tais transformações teriam se dado a partir da ação conjunta de portugueses e Imbangala na região. Apesar de Selma Pantoja e David Birmingham considerarem a importância da presença Imbangala no Ndongo nesse momento, e a associação entre estes e os portugueses, não a têm como fator determinante para a avaliação da presença portuguesa na região. De acordo com Joseph Miller, a chegada dos portugueses somada à chegada dos Imbangala teria revolucionado a geografia e instituições políticas dos $\mathrm{Mbundu}^{48}$. Segundo ele, quando os dois invasores se uniram em busca de escravos, condenaram à derrota os antigos reis

46 BIRMINGHAM, David. Op. cit., pp. 80-81.

47 Ibidem, p. 42.

48 MILLER, Joseph C. Op. cit., p. 174. 
Mbundu. Como já dissemos aqui, o autor defende que eles conseguiram que os ngola a kiluanje fossem reduzidos a governantes fantoches e quase sem poder, criando, em sua substituição, um conjunto completamente novo de estados. Portugueses e Imbangala teriam juntado as suas forças para estabelecer esse novo conjunto de estados traficantes de escravos que num certo sentido diferiam pouco quanto ao seu impacto sobre os Mbundu. Segundo o autor,

Tanto os Portugueses como os Imbangala representavam desafios similares, de enormes proporções, quando encarados na perspectiva dos grupos de parentes dos Mbundu, cujos antepassados tinham preservado a autonomia das linhagens contra ameaças dos titulares mavunga do Libolo e o reino centralizador do ngola a kiluanje. Nenhum dos novos invasores possuía linhagens do tipo que os Mbundu consideravam fundamentais para uma sociedade humana. ${ }^{49}$

Eram estrangeiros vindos de muito longe e nenhum deles fazia da agricultura o seu modo de vida, eles roubavam ou comerciavam os produtos dos agricultores locais. De acordo com Miller, os portugueses e os Imbangala tinham a percepção dos seus interesses comuns, além de, talvez, perceberem suas semelhanças aos olhos dos Mbundu. Ainda de acordo com o autor os Mbundu receavam mais os Imbangala que os portugueses, já que antes da aliança com os Imbangala os portugueses não tinham ido muito além do rio Kwanza ${ }^{50}$. Porém, com o apoio dos Imbangala esta configuração muda, em 1615 muitos governantes Mbundu a sul do rio Bengo, incluindo o ngola a kiluanje renderam-se em consequência das campanhas do governador Bento Banha Cardoso em aliança com os Imbangala.

Portugueses e Imbangala se complementaram na busca de fazer frente aos Mbundu já que os Imbangala correspondiam às necessidades portuguesas em quase todos os aspectos, principalmente no militar. As precárias posições desses dois grupos a norte do Kwanza mantiveram-nos num firme acordo contra as linhagens Mbundu. Segundo Miller, os portugueses teriam fixado os Imbangala do Kulaxingo próximo de Ambaca e o próprio presídio era ocupado por Imbangalas. O autor defende que a fixação de grupos Imbangala nas proximidades do Ndongo teria gerado um grande número de escravizados provenientes dessa região, inclusive para o tráfico ilegal. Devido ao grande número de cativos e em consequência da parceria econômico-militar entre Imbangala e portugueses, um empório de escravos teve de se desenvolver próximo à principal povoação Imbangala. À medida que os governadores portugueses tentavam consolidar um controle muito tênue entre os rios 
Kwanza e Bengo, enfrentavam fortes disputas, por isso exploravam avidamente as tendências secessionistas do kilombo e ajudaram a criar o anel de uma clientela de reis Imbangala que rodeava a área sob controle português, cerca de $1650^{51}$.

De acordo com o autor, o papel dos Imbangala na "conquista" portuguesa de Angola ajuda a explicar as características da história europeia nesta parte da África durante o século XVII. A estrutura política dos Imbangala e sua relação com as populações Mbundu e Ovimbundu esclarecem grande parte das guerras angolanas, tanto contra reis africanos, como contra rivais europeus. Os Imbangala deram aos portugueses os seus primeiros sucessos consistentes contra os Mbundu na década após 1610. Tornaram possível o aumento do tráfico de escravos que transformou Angola de periferia do Congo, na área de maior interesse econômico e político dos portugueses. As oportunidades de lutar ao lado dos exércitos Imbangala influenciaram decisões estratégicas. Os estados dos mercenários Imbangala protegiam as fronteiras que acabaram por emergir dos conflitos ocorridos nas primeiras décadas do século XVII ${ }^{52}$. Estas terras estavam rodeadas por um anel de novos estados Mbundu, fundados em meados do século XVII por titulares Lunda que chefiavam bandos de Imbangala. e qQue eram os principais fornecedores de escravos em tempos de paz e mercenários durante as guerras. Além disso, os Imbangala encorajaram o desenvolvimento do contrabando que atraiu os holandeses e outros para a costa de Luanda.

\section{Considerações finais}

Este artigo buscou identificar a forma pela qual os historiadores David Birmingham, Joseph Miller e Selma Pantoja apresentam nos textos aqui selecionados os desdobramentos para o reino do Ndongo da presença estrangeira em seu território e de sua inserção no comércio atlântico de escravizados. Através da identificação dos principais elementos apresentados por cada um dos autores a respeito dos acontecimentos vivenciados pelo Ndongo nas primeiras décadas após o início dos contatos com os negociantes portugueses, e posteriormente com a Coroa portuguesa, apresentamos brevemente as consequências, como escolhemos chamar, da presença portuguesa no Ndongo que podem ser apreendidas através desses textos. E que, se considerando a relevância historiográfica dessas obras, podem ser apresentadas como algumas das principais consequências da presença portuguesa nessa região até, pelo menos, grande parte do século XVII. 
É preciso salientar que as obras analisadas neste artigo não têm como objetivo próprio identificar ou analisar as consequências da presença estrangeira no Ndongo de forma direta. Portanto, buscamos encontrar dados que os textos trazem, ao trabalhar outras questões, que pudessem responder a pergunta aqui formulada. Por isso, os dados apresentados neste artigo são o resultado de uma leitura atenta que buscou ser fiel aos dados apresentados por esses autores acerca da história da África Centro-Ocidental, dos povos Mbundu e do reino do Ndongo, considerando os principais assuntos e problemáticas por eles discutidas; bem como são fruto de nossa ação interpretativa que certamente teve papel considerável.

Os autores trabalhados apresentam diversos indícios de que durante o século XVII no Ndongo e seu entorno muitas foram as modificações vividas por sua população. De maneira que pudemos constatar que, na visão apresentada por esses autores, o contato com os estrangeiros estabelecidos em Luanda trouxe consideráveis consequências para essa região. De modo geral, as obras analisadas não apresentam grandes divergências entre si no que se refere a essas modificações. Em alguns momentos percebem-se pequenas divergências na forma de tratar determinada questão, como é o caso de Joseph Miller que compreende as mudanças geradas pela presença portuguesa a partir de sua associação com os grupos Imbangala, o que não acontece com os demais autores. Porém, em sua maior parte os textos analisados concordam em relação aos apontamentos feitos a respeito das transformações vividas nesse momento no Ndongo. Esses autores, inclusive são interlocutores entre si como podemos perceber em diversos momentos, principalmente no caso de Selma Pantoja que tem David Birmingham e Joseph Miller como grandes referências.

Como pudemos verificar, os autores, apesar de algumas vezes se valendo de argumentos diferentes, concordam em relação à maioria das consequências vividas pelo Ndongo, principalmente aquelas de maior impacto e abrangência, como é o caso da destruição e o despovoamento que atingiu a região. Mas, foi possível identificar em cada um deles algo que sobressai na análise de determinado autor e que não aparece nos demais. O que nos demonstra que, apesar de existirem consensos no que se refere à análise dos desdobramentos da relação entre os portugueses e os Mbundu do Ndongo, existe espaço para o estudo de peculiaridades e olhares diferenciados. No trabalho de cada um dos autores colocam-se questões singulares que podem resultar de interesse pessoal, de interpretações particulares ou de dados obtidos em fontes que os outros não tiveram acesso ou não utilizaram. 
As transformações apontadas por essas obras podem ser percebidas, em grande parte, como consequências da presença portuguesa. Porém, precisamos destacar nossa constatação de que dentro do olhar e da perspectiva expressa pelos autores por nós analisados, essas consequências se colocam como o resultado de uma relação dialética que se dava entre os portugueses e os habitantes do Ndongo. São consideradas consequências da presença portuguesa porque se ligam mais ou menos diretamente às demandas geradas pelo contato com os estrangeiros, e não teriam necessariamente se dado se não fosse esse fator. Mas, são resultado também dos interesses dos próprios Mbundu, das alternativas buscadas, caminhos encontrados para lidar com as novas demandas vinculadas à associação ao tráfico transatlântico de escravizados, com os acordos comerciais, políticos e militares com os membros da administração portuguesa estabelecida em Luanda, com a busca dos estrangeiros de adentrar e se fixar em seu território, entre outros fatores,. e com as diferentes formas de resistir aos avanços estrangeiros em seu território.

\section{Referências Bibliográficas:}

BIRMINGHAN, David. A África Central até 1870: Zambézia, Zaire e o Atlântico Sul. Luanda: ENDIPU/UEE, s/d.

MILler, Joseph C. Poder Político e Parentesco: os Antigos Estados Mbundu em Angola. Luanda: Arquivo Histórico Nacional, 1995.

PANTOJA, Selma. Nzinga Mbandi: mulher, guerra e escravidão. Brasília: Thesaurus, 2000.

\section{Dados da autora}

\section{Luciana Lucia da Silva}

Graduada em História pela Universidade Federal do Rio de Janeiro. Apresentou a monografia intitulada "O reino do Ndongo e a presença portuguesa, século XVII” para a obtenção do título de Bacharel em História. Iniciou no ano de 2017 o curso de Mestrado em História Social no Programa de Pós Graduação em História Social (PPGHIS) do Instituto de História da UFRJ. Participa do Laboratório de Estudos Africanos (LEÁFRICA-IH/UFRJ) desde 2011. 